\title{
Estrus cycle monitoring of captive collared peccaries (Pecari tajacu) in semiarid conditions ${ }^{1}$
}

\author{
Keilla M. Maia², Gislayne C.X. Peixoto², Lívia B. Campos², José Artur B. Bezerra², \\ Aracelly R.F. Ricarte ${ }^{2}$, Nei Moreira ${ }^{3}$, Moacir F. Oliveira ${ }^{2}$ and Alexandre R. Silva ${ }^{2 *}$
}

\begin{abstract}
Maia K.M., Peixoto G.C.X., Campos L.B., Bezerra J.A.B., Ricarte A.R.F., Moreira N., Oliveira M.F. \& Silva A.R. 2014. Estrus cycle monitoring of captive collared peccaries (Pecari tajacu) in semiarid conditions. Pesquisa Veterinária Brasileira 34(11):11151120. Laboratório de Conservação de Germoplasma Animal, Universidade Federal Rural do Semi-Árido, BR-110 Km 47, Presidente Costa e Silva, Mossoró, RN 59625-900, Brazil. E-mail: legio2000@yahoo.com

Collared peccaries (Peccary tajacu) are among the most hunted species in Latin America due the appreciation of their pelt and meat. In order to optimize breeding management of captive born collared peccaries in semiarid conditions, the objective was to describe and correlate the changes in the ovarian ultrasonographic pattern, hormonal profile, vulvar appearance, and vaginal cytology during the estrus cycle in this species. During 45 days, females $(n=4)$ were subjected each three days to blood collection destined to hormonal dosage by enzyme immunoassay (EIA). In the same occasions, evaluation of external genitalia, ovarian ultrasonography and vaginal cytology were conducted. Results are presented as means and standard deviations. According to hormonal dosage, six estrous cycles were identified as lasting $21.0 \pm 5.7$ days, being on average 6 days for the estrogenic phase and 15 days for the progesterone phase. Estrogen presented mean peak values of $55.6 \pm 20.5$ $\mathrm{pg} / \mathrm{mL}$. During the luteal phase, the high values for progesterone were $35.3 \pm 4.4 \mathrm{ng} / \mathrm{mL}$. The presence of vaginal mucus, a reddish vaginal mucosa and the separation of the vulvar lips were verified in all animals during the estrogenic peak. Through ultrasonography, ovarian follicles measuring $0.2 \pm 0.1 \mathrm{~cm}$ were visualized during the estrogen peak. Corpora lutea presented hyperechoic regions measuring $0.4 \pm 0.2 \mathrm{~cm}$ identified during luteal phase. No significant differences $(P>0.05)$ between proportions of vaginal epithelial cells were identified when comparing estrogenic and progesterone phases. In conclusion, female collared peccaries, captive born in semiarid conditions, have an estral cycle that lasts $21.0 \pm 5.7$ days, with estrous signs characterized by vulvar lips edema and hyperemic vaginal mucosa, coinciding with developed follicles and high estrogen levels.
\end{abstract}

INDEX TERMS: Estrus cycle, Tayassu tajacu, hormonal dosage, ultrasonography.

RESUMO.- [Monitoramento de ciclo estral em catetos (Pecari tajacu) criados em cativeiro em condições semiáridas.] Os catetos (Peccary tajacu) estão entre as espécies mais caçadas na América Latina devido a apreciação de seu couro e carne. No intuito de otimizar o manejo produtivo

\footnotetext{
${ }^{1}$ Received on February 8, 2014.

Accepted for publication on July 2, 2014.

${ }^{2}$ Laboratório de Conservação de Germoplasma Animal, Universidade Federal Rural do Semi-Árido (Ufersa), BR-110 Km 47, Presidente Costa e Silva, Mossoró, RN 59625-900, Brazil. *Corresponding author: legio2000@ yahoo.com

${ }^{3}$ Universidade Federal do Paraná, Setor Palotina, Rua Pioneiro 2153, Jardim Dallas, Palotina, PR 85950-000, Brazil.
}

de catetos nascidos em cativeiro sob condições semiáridas, o objetivo foi descrever e correlacionar as modificações verificadas no padrão ultrassonográfico ovariano, o perfil hormonal, a aparência vulvar, e a citologia vaginal durante o ciclo estral nesta espécie. Durante 45 dias, fêmeas $(n=4)$ foram submetidas a coleta de sangue destinado a dosagem hormonal por meio de teste imuno-enzimático (EIA). Na mesma ocasião, foram conduzidas a avaliação da genitália externa, a ultrassonografia ovariana e a citologia vaginal. Os resultados são apresentados com média e desvio padrão De acordo com a dosagem hormonal, foram identificados seis ciclos estrais, com duração $21,0 \pm 5,7$ dias, sendo em média 6 dias de fase estrogênica e 15 dias de fase proges- 
terônica. 0 estrógeno apresentou valores médios de pico de 55,6 $\pm 20,5 \mathrm{pg} / \mathrm{mL}$. Durante a fase luteal, os valores mais altos alcançados pela progesterona foram $35,3 \pm 4,4 \mathrm{ng} / \mathrm{mL}$. A presença de muco vaginal, mucosa vaginal hiperêmica e separação dos lábios vulvares foi identificada em todos os animais durante o pique estrogênico. Por meio da ultrassonografia, folículos ovarianos medindo $0,2 \pm 0,1 \mathrm{~cm}$ foram visualizados durante o pique estrogênico. Corpos lúteos apre-

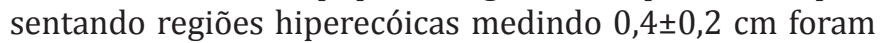
identificados na fase luteal. Nenhuma diferença significativa $(\mathrm{P}>0,05)$ entre as proporções de células epiteliais vaginais foram identificadas quando comparadas as fases estrogênica e progesterônica. Em conclusão, fêmeas de cateto, nascidas em cativeiro sob condições semiáridas, apresentam um ciclo estral que dura 21,0 $\pm 5,7$ dias, com sinais de estro caracterizados por edema de lábios vulvares e hiperemia da mucosa vaginal, coincidindo com desenvolvimento de folículos ovarianos e elevados níveis de estrógeno.

TERMOS DE INDEXAÇÃO: Ciclo estral, Tayassu tajacu, dosagem hormonal, ultrassonografia.

\section{INTRODUCTION}

Collared peccaries (Peccary tajacu) are among the most hunted species in Latin America due the appreciation of their pelt and meat. Thus, knowledge of reproductive biology is of paramount importance to optimize reproductive management and future application or assisted reproduction techniques in the ex situ conservation of the species. However, information on their reproductive aspects is scarce, and appropriate management practices have not yet been developed for them (Mayor et al. 2007a). The development of reliable methods for visualizing the reproductive tract and monitoring the reproductive cycle of wild species is required to optimize breeding management in captivity (Hildebrandt et al. 2000, Cervantes et al. 2013).

In recent years, the real-time ultrasound appears as an important tool for the study of ovarian dynamics during estrous cycle in many domestic mammals, such as the sow (Schwarz \& Wierzchos 2010). This image technique has been adapted for use in wild animals (Hermes et al. 2000, McCorkell et al. 2013), but there is only few studies that reports its use for pregnancy diagnosis (Mayor et al. 2005) and testicular biometry (Peixoto et al. 2012) in collared peccaries, and no ultrasonographic information is available regarding ovarian structures found during estrous cycle.

In fact, information regarding estrous cycle in peccaries remains scarce and limited to individuals captured from the Amazon Forest. In these animals, the $17 \beta$-estradiol dosage presented a concordance in the estrus diagnosis to the vulvar appearance (Mayor et al. 2007b). Recently, the use of vaginal cytology was suggested for the estrus cycle monitoring in such animals (Guimarães et al. 2011). The comprehension of the relationship among ovarian dynamics and endocrine or morphological changes during estrous cycle would contribute for the understanding of female reproductive physiology in above-mentioned species.

The objective of the present study was to describe and correlate the ovarian ultrasonographic pattern, the hormo- nal profile, the vulvae appearance, and the vaginal cytology during the estrus cycle of a group of captive born female collared peccaries in the Brazilian semi-arid region.

\section{MATERIALS AND METHODS}

The UFERSA Ethics committee approved this experimental protocol, and the animal care procedures (Process no 23091.000250/ 2011-34). A group of four sexually mature, nulliparous, adult female collared peccaries (age 16.0 \pm 0.4 months) and weighting $20.6 \pm 1.1 \mathrm{~kg}$ respectively, was used. The animals were captive born in the Centre of Multiplication of Wild Animals/UFERSA, located in the northeast Brazil (Mossoró, RN, Brazil; 5¹0=S, 37¹0=W). The climate is typical semi-arid, with an annual temperature ranging from 21 to $36^{\circ} \mathrm{C}$ and a daily temperature variation of $7-14^{\circ} \mathrm{C}$, with an average relative humidity of $68 \%$. The animals were isolated from the others three months before the commencement of the study and maintained under a $12 \mathrm{~h}$ natural photoperiod. They were maintained outdoors in groups of three in paddocks $(20 \times 3 \mathrm{~m})$ with a covered area $(3 \times 3 \mathrm{~m})$ and fed sow food and fruits (with water available ad libitum).

At the first day of the experiment, animals were physically restrained using a hand net and anesthetized using intravenous administration of propofol (Propovan ${ }^{\circledR}$, Cristalia, Fortaleza, Brazil), given as a bolus ( $5 \mathrm{mg} / \mathrm{kg}$ ) (Souza et al. 2009). This procedure was conducted in order to perform the abdominal trichotomy, to facilitate the ovarian ultrasonography. Subsequently, animals were only manually restrained by the use of a hand net at every three days. Procedures were always initiated at 5:00 A.M. and finished at 8:00 A.M, from June to August 2010. During these occasions, collection of blood samples and vaginal smears, and ovarian ultrasonography were conducted. Also, alterations in the external genitalia were evaluated as described by Mayor et al. (2007b).

A complete estrous cycle was defined as the interval between two estrogenic peaks. The estrogenic and progesterone phases of the estrous cycle were identified according to the estrogen and progesterone values previously established for collared peccaries (Mayor et al. 2006b, Mayor et al. 2007a). To measure the serum concentrations of these hormones, blood samples were obtained at each restraint procedure. Blood was collected into silicon tubes by cephalic or saphenous venipuncture and centrifuged at 2000 $\mathrm{G}$ for 15 min within $2 \mathrm{~h}$. The serum was separated and stored at $-18^{\circ} \mathrm{C}$ until assayed. Dosing of estradiol and progesterone was performed through the use of commercial enzyme immunoassay (EIA) Kits (Max-Planck Ring 21-D 65205, Human GmbH, Wiesbaden, Germany) containing 12 microtitre strips (MIC) with 8 holes covered with anti-estradiol or anti-progesterone antibodies (rabbit). The procedure was performed according to the recommendations of the kit's manufacturer. The analytical sensitivity was determined to approximately 3-6 pg/mL of estradiol, and approximately $0.03-0.07 \mathrm{ng} / \mathrm{mL}$ of progesterone.

The ovaries were evaluated by ultrasonography using a 5-7.5 $\mathrm{MHz}$ microconvex array transducer and a B-mode, real-time, portable scanner (Aquila Vet, Pie Medical ${ }^{\circledR}$, Nutricell, Campinas, SP, Brazil). Animals were positioned in lateral recumbence. Five milliliters of ultrasound transmission gel were applied on the abdominal wall. The abdomen was completely scanned, and the kidneys were identified. Caudally to the kidneys, both ovaries were identified and evaluated for echoic appearance, and echo texture. The following measurements of ovaries were carried by using electronic cursors integrated into the ultrasound machine: length (from the end of capitata to the end of the caudate), and width (dorsal-ventral direction). Dimensions of the ovarian structures such as follicles and corpora lutea were also recorded. Images were sto- 
red for further analysis and establishment of relationship to other physiologic parameters.

Vaginal smears were obtained by introducing a cotton swab into the caudal vagina. After rubbing the swab against the vaginal wall, the cells were transferred to a glass slide by gently rolling the swab. Finally, the smear was allowed to air dry and stained with a Diff-Quick stain (Instant-Prov ${ }^{\circledR}$, Newprov, Pinhais, PR, Brazil). As previously described for the same species (Guimarães et al. 2011), two hundred cells were counted under light microscopy (x400), and the results were recorded as the proportions of parabasal, intermediate and superficial cells counted. The appearance and the relative proportions of these cell types were correlated to the hormonal levels for each animal, in order to identify if the predominance of a determinate cellular type allowed the differentiation between estrogenic and progesterone phases.

Statistical analyses were conducted with Statview 5.0 (SAS Institute Inc., Cary, USA). Data were expressed as the mean and standard deviation (SD). A simple linear regression model was used to identify associations between the hormonal profile (independent variables) and vaginal cytology (dependent variables). To evaluate the effect of the estrus phase (estrogenic or progesterone phase) on the proportion of the vaginal epithelial cells, data were subjected to ANOVA, using the General Linear Model Procedure (GLM). Data for ovarian morphometry were analyzed through Student's t test. For all analyses, $\mathrm{P}<0.05$ was considered significant.

\section{RESULTS}

During 45 days, a total of six estrous cycles were identified in four collared peccaries. In two individuals, two different consecutive cycles were monitored in each; in the other two animals, only one cycle was evaluated. Estrous cycles lasted 21.0 \pm 5.7 days, being 6 days for estrogenic phase and 15 days for progesterone phase on average. Cycles as long as 27 days, and others as short as 15 days were also identified. Mean values of $55.6 \pm 20.5 \mathrm{pg} / \mathrm{mL}$ were found for the estrogen peak. During the progesterone phase, peak values for progesterone were $35.3 \pm 4.4 \mathrm{ng} / \mathrm{mL}$. Figure 1 presents the hormonal profile during the estrus cycle for each female.

Through ultrasonography, an ovary detection rate of $100 \%$ was achieved by utilizing both frequencies of the microconvex transducer (5.0/7.5 MHz). Eventually, the identification of the internal ovarian structures was not possi-
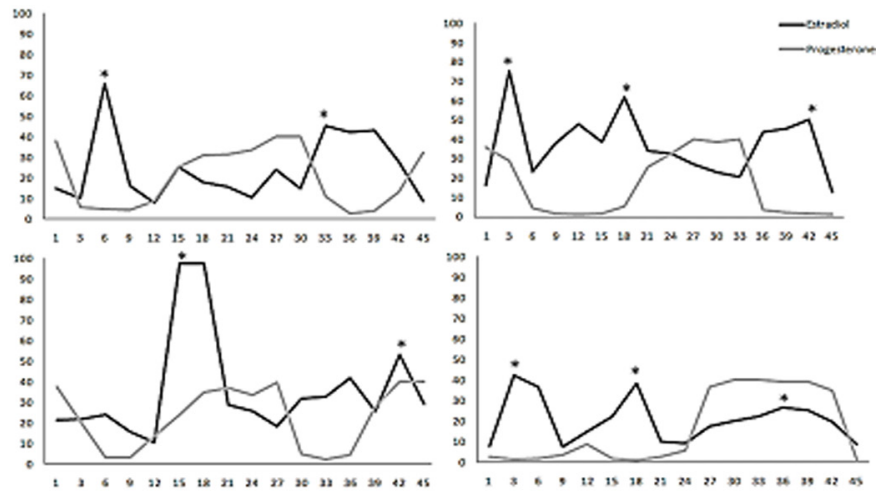

Fig.1. Serum estradiol (pg/ml) and progesterone (ng/ml) profiles of cyclic female collared peccaries (Pecari tajacu) evaluated for 45 days. Each graph represents a female $(n=4)$. Estradiol peak.

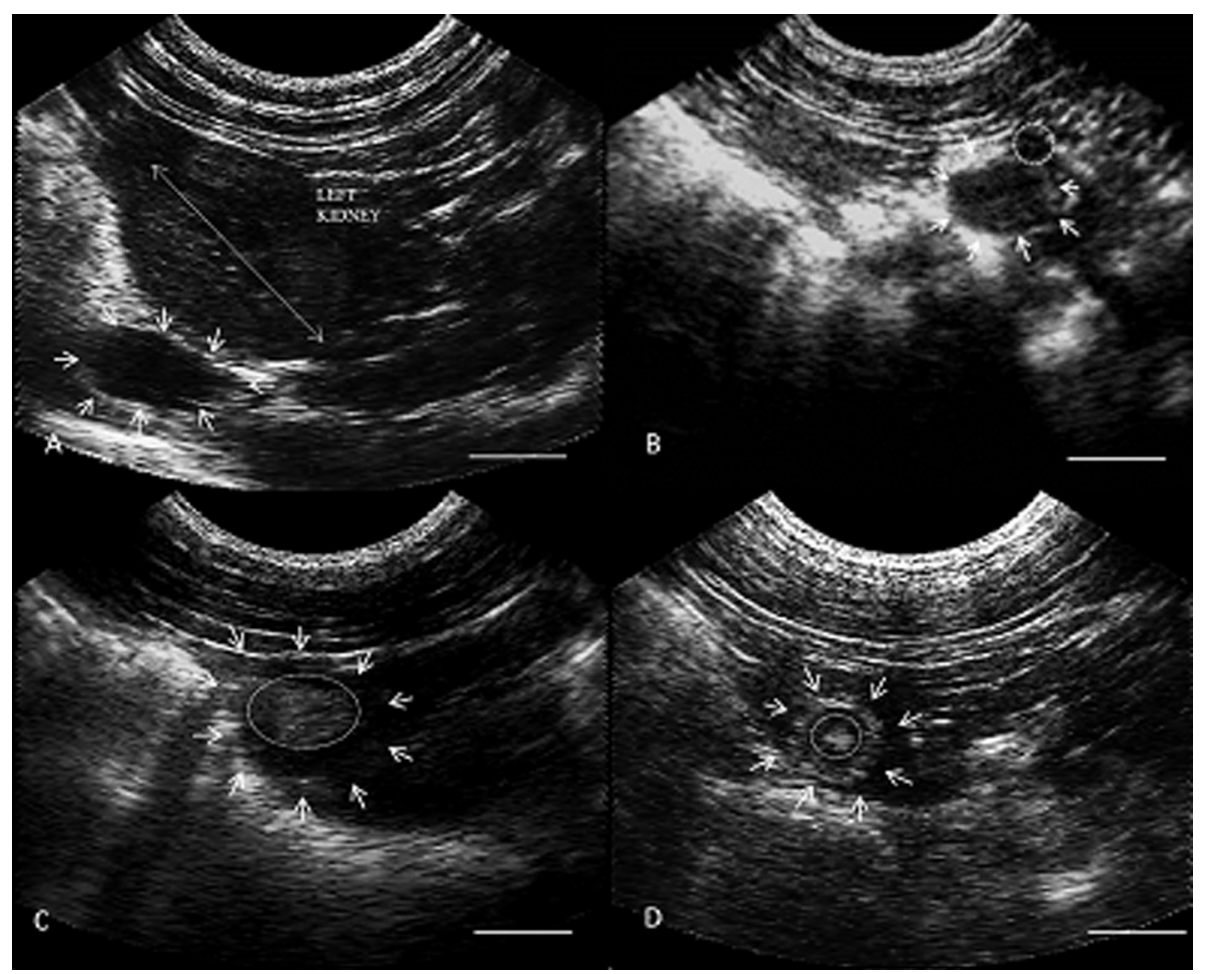

Fig.2. Ultrasonographic images of collared peccary (Pecari tajacu) ovaries (white arrows). (A) Left ovary appearing as a well-defined structure, oval shaped and slightly hypoechoic in relation to the surrounding tissue, located caudally to the kidney. (B) Presence of a large antral follicle (circle) projected onto surface during estrogenic phase. (C) Presence of a large corpus luteum (ellipsis) in the ovary during progesterone phase. (D) Presence of a small corpus luteum (ellipsis) in the ovary during progesterone phase. Scale bar $=1 \mathrm{~cm}$. 
ble, which made the accurate monitoring of the sequential events involved to the ovarian dynamics difficult all along the estrus cycle. All ovaries appeared as well-defined structures, oval shaped and slightly hypoechoic in relation to the surrounding tissue, located caudally to the kidneys (Fig.2A). The ovaries showed heterogeneous echotexture when follicles and/or corpora lutea were present in the parenchyma. Ovarian morphometry detected by ultrasound is summarized in Table 1 . The right and left ovaries were symmetric structures ( $\mathrm{p}>0.05)$. The length of the right ovary was significantly higher in the progesterone phase when compared to follicular phase $(\mathrm{p}<0.05)$. Ovarian follicles were identified in all animals during the estrogenic peak as regular circular structures containing anechoic fluid, sometimes projected onto the surface of the ovary. The larger

Table 1. Ovarian morphometry detected by ultrasonographic evaluation of female collared peccaries (Pecari tajacu) during different phases of the estrous cycle

\begin{tabular}{lccccc}
\hline & \multicolumn{2}{c}{ Right ovary } & & \multicolumn{2}{c}{ Left ovary } \\
\cline { 2 - 3 } \cline { 5 - 6 } & Length $(\mathrm{cm})$ & Width $(\mathrm{cm})$ & & Length $(\mathrm{cm})$ Width $(\mathrm{cm})$ \\
\hline Estrogenic phase & $1.0 \pm 0.1^{\mathrm{a}}$ & $0.9 \pm 0.1^{\mathrm{a}}$ & & $1.0 \pm 0.1^{\mathrm{a}}$ & $0.9 \pm 0.1^{\mathrm{a}}$ \\
Progesterone phase & $1.2 \pm 0.1^{\mathrm{b}}$ & $1.0 \pm 0.1^{\mathrm{a}}$ & & $1.0 \pm 0.1^{\mathrm{a}}$ & $0.9 \pm 0.1^{\mathrm{a}}$
\end{tabular}

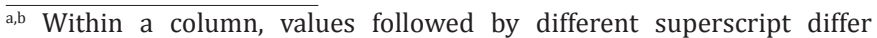
$(\mathrm{P}<0.05)$. diameter reached by the pre-ovulatory follicles during estrogenic phase was $0.2 \pm 0.1 \mathrm{~cm}$ (Fig. $2 \mathrm{~B}$ ). In the progesterone phase, corpora lutea were ovoid bodies protruded onto the ovary surface, presenting a mean diameter of $0.4 \pm 0.2$ $\mathrm{cm}$, and reaching dimensions as large as $1.0 \mathrm{~cm}$ during the higher progesterone levels (Fig.2CD). The appearance of these structures was heterogeneous, since they presented a hyperechoic wall surrounding a hypoechoic image in the center, which suggests the presence of a fluid content.

As external signs of the estrus, the presence of vaginal mucus, a reddish vaginal mucosa and the vaginal opening (separation of the vulvar lips) were verified in two animals at three days before the estrogenic peak, and remains for the third day after that peak. For the other two animals, these characteristics were only verified on the exact day of the estrogenic peak.

Regarding vaginal cytology (Fig.3), the presence of parabasal, intermediate and superficial cells was identified in all vaginal smears, but no basal cells were verified during any moment. The presence of erythrocytes and leucocytes, especially neutrophils, was verified in some smears close to the estrogen peak. No correlations amongst the hormonal profiles and vaginal cytology were identified during any moment of the cycle $(\mathrm{P}>0.05)$. A smooth predominance of parabasal cells followed by enucleated superficial cells was
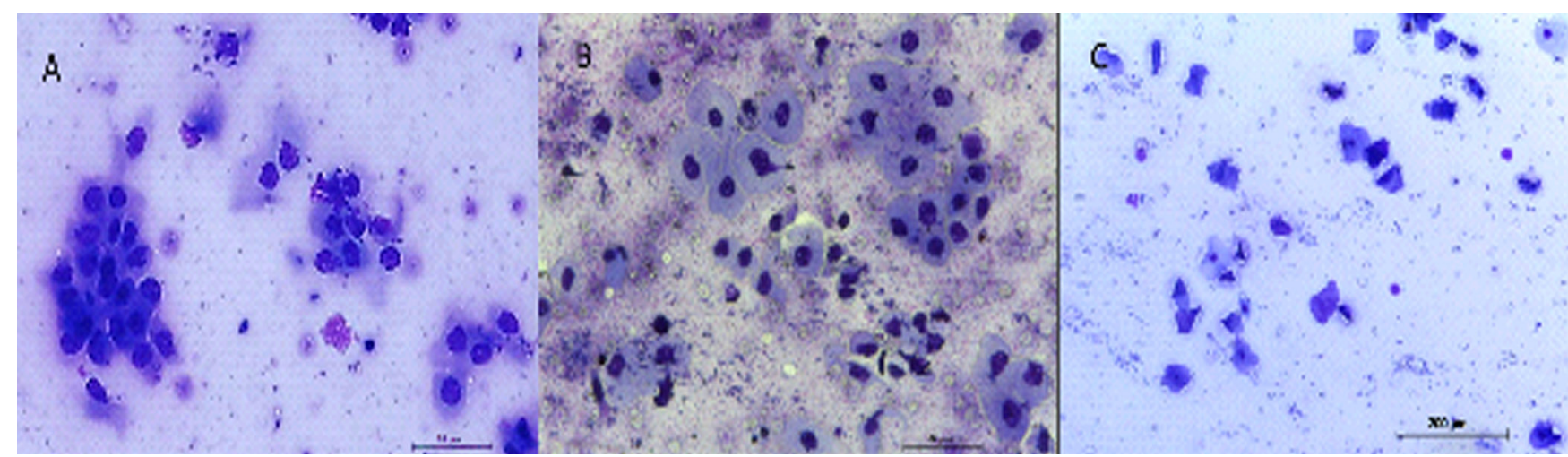

Fig.3. Epithelial cells found in vaginal cytology of of cyclic female collared peccaries (Pecari tajacu): (A) parabasal, (B) intermediate, and (C) superficial cells.
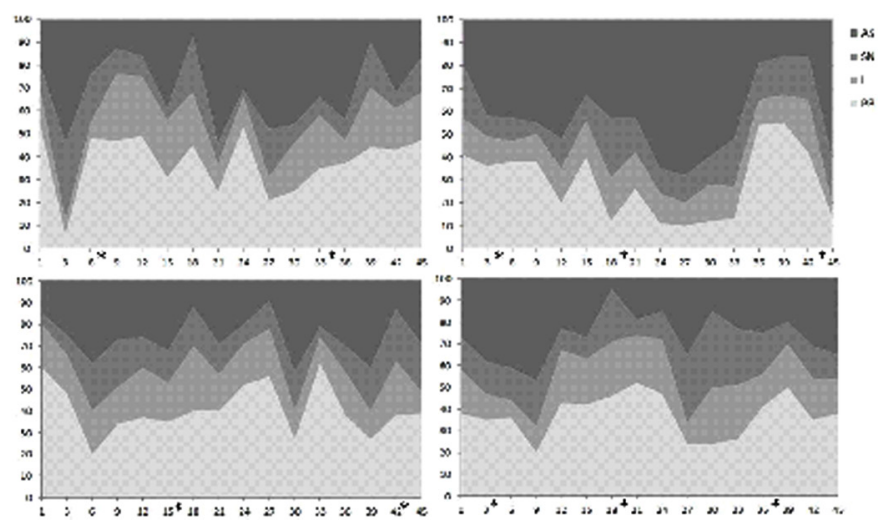

Fig.4. Proportion of epithelial vaginal cells classified as parabasal (PB), intermediate (I), nucleated superficial (NS) and enucleated superficial (ES) of cyclic female collared peccaries (Pecari tajacu) evaluated for 45 days. Each graph represents a female $(\mathrm{n}=4)$. * Correspondent day for estradiol peak. detected during all the cycle in all the individuals. After grouping data from all the animals, no significant differences between the proportions of vaginal cells were identified (Fig.4) when comparing estrogenic and progesterone phases of the estrous cycle $(\mathrm{P}>0.05)$.

\section{DISCUSSION}

To the best of our knowledge, the ultrasonographic patterns of the ovary and its structures were for the first time demonstrated during the estrous cycle in collared peccaries. In spite of the efficiency in identifying the ovarian structures, an accurate monitoring of the sequential events related to the ovarian dynamics by the transcutaneous ultrasonography was hampered by the anatomical characteristics of the ovary. This organ is completely enveloped by a bursa ovarica (Guimarães et al. 2012), similarly as related for domestic swine (Knox \& Althouse 1999, Lopes et 
al. 2014). In this species, it is suggested that transrectal method would provide an easier finding of ovaries and a more reliable follicle count (Waberski et al. 1999). By this moment, the use of transrectal ultrasonography in collared peccaries was not reported, maybe due to the limitations related to the size of the individuals, and due to the need of repetitive anesthesia for sequential examinations.

The main limitations of repeatable ultrasound examinations in non-domestic animals are the poor availability of biological material (Comizolli et al. 2000) and the risk of physical or chemical restraint (Hildebrandt et al. 2000). In the present research, we had to use a reduced number of animals due to ethical recommendations, since that the procedure of repetitive restraint is very stressful and sometimes harmful for the individuals. In fact, it is known that the stress, as a consequence of management practices, could negatively interfere in the dynamics of the peptides and steroidal hormones involved in reproductive function (Dobson et al. 2003). However, we believe that such interference did not happen in the present study, since all females presented regular cycles, with hormonal peaks similar to those previously described for the species (Mayor et al. 2006b, 2007a). Anyway, the development of better restraint methods for collared peccaries is required.

The larger dimensions found for follicular structures during the estrogenic peak correspond to those previously described for large antral follicles $(\sim 0.23 \mathrm{~cm})$, through histological analysis, for the same species (Mayor et al. 2006a). Otherwise, the luteal diameter found in the same previous study $(\sim 0.7 \mathrm{~cm})$ is into the range verified by ultrasonography. However, we emphasize that sometimes ultrasonography was not efficient enough to evaluate all the dimensions of the corpora lutea and the values of such structures could be underestimated. According to Waberski et al. (1999), due to the similar echogenicity between corpora lutea and ovarian stroma in sows, corpora lutea are only visible for well-trained investigators in approximately $50 \%$ of sows.

Present results demonstrate estrous cycles of $21.0 \pm 5.7$ days in average, for female collared peccaries housed in captivity under semiarid climate. Closer values were found for the peccaries captured in Amazon under equatorial climate, in which cycles of $23.5 \pm 2.1$ days were described (Mayor et al. 2006b). Mean values for the estrogen peak found in the present study $(55.6 \pm 20.5 \mathrm{pg} / \mathrm{mL})$ were closer to those described for the same species under equatorial conditions $(53.4 \pm 8.1 \mathrm{pg} / \mathrm{mL}$ ), determined by ELISA (Mayor et al. 2007a). Regarding the progesterone phase, peak values verified for progesterone, $35.3 \pm 4.4 \mathrm{ng} / \mathrm{mL}$, were similar to those reported for the Amazon collared peccaries, $30.8 \pm 4,9 \mathrm{ng} / \mathrm{mL}$, also using ELISA (Mayor et al. 2006b). Up to this moment, all the research conducted on collared peccaries that report hormonal measurements (Mayor et al. 2006b, Mayor et al. 2007a) are based on blood collection, even assuming that repetitive restraint of the animals could be stressful and cause several injuries for the individuals. Therefore, it was suggested that further studies should be conducted in order to monitor the reproductive cycle of this species by using fecal metabolites as recently reported for wild boars, Sus scrofa (Macchi et al. 2010).
As verified for peccaries, the existence of a variation regarding the duration of estrus cycles was previously described for Saanen goats bred under semiarid climate, in which it is suggested that long cycles could be associated to a certain anestrous degree, because of the corpus luteum persistence (Lopes Jr et al. 2001). In fact, a larger luteal phase (19.5 \pm 2.1 days) was verified for the female collared peccaries when presenting longer cycles. On the other hand, short intervals between estrogenic elevations could indicate the occurrence of different follicular waves during the estrus cycle of collared peccaries, because it was previously suggested that there are follicular waves involving the synchronous growth of a cohort of follicles, from which several seem to be selected to continue development in this species (Mayor et al. 2006b). The occurrence of different follicular waves in the same cycle is well studied in wood bison (McCorkell et al. 2013) and cattle, in which the majority of estrous cycles are comprised of two or three waves (Adams et al. 2008); but in peccaries, these events lack further investigations.

The alterations observed in the external genitalia during the estrus were similar to those reported for the Amazon collared peccaries (Mayor et al. 2007b), and an individual variation with regards to the duration of this characteristics was evidenced. This evidence is also described for domestic sows and is related to the action of the high estrogen levels on the female genital system (Ostersen et al. 2010, Bertoldo et al. 2012).

It was previously demonstrated that female collared peccaries in the follicular phase presented a thicker vaginal epithelium than pregnant females and females in the luteal phase, as detected by vaginal histology (Mayor et al. 2004). Furthermore, a correspondence between vaginal cytology and estradiol profile was suggested for the Amazonian individuals (Mayor et al. 2007b). However, the present results indicate that there are no significant changes in the proportion of the vaginal epithelial cells between estrogenic and progesterone phases by vaginal cytological examination, similarly as reported for domestic sows (Wilson 1926). Also, no significant relation amongst the vaginal epithelial cells and reproductive steroids were found during the estrus cycle of collared peccaries bred in captivity under semiarid conditions. The existence of variations between individuals or even between different groups concerning the reproductive aspects could not be discarded.

At compiling all data derived from collared peccaries, we could infer that during estrogenic phase, ultrasonography can detect the presence of growing ovarian follicles that are related to elevations in the estrogenic serum concentrations and vulvar changes, however, only the rising of erythrocytes and neutrophils are detected trough vaginal cytology in this moment. Otherwise, corpora lutea are found in the ovary by ultrasonography when high progesterone levels are detected by hormonal dosage and no alterations in the vulva or vaginal cytology are evident. We emphasize that after the experiment, all female continue presenting regular cycles. Then, they were included in the breeding program, acting as excellent breeders.

In conclusion, female collared peccaries, captive born in semiarid conditions, have an estral cycle that lasts 21.0 \pm 5.7 
days, with estrous signs characterized by vulvar lips edema and hyperemic vaginal mucosa, coinciding with developed follicles and high estrogen levels.

Acknowledgements.- The authors thank Dr. Sidney M. Sakamoto from the Multidisciplinary Laboratory/UFERSA for technical assistance during the hormonal assays; and M.Sc. Bruno R. Simão from the Departamento de Ciências Ambientais e Tecnológicas/UFERSA for statistical assistance. G.C.X. Peixoto, J.A.B. Bezerra, M.F. Oliveira, and A.R. Silva were supported by grants from CNPq (National Research Council).

\section{REFERENCES}

Adams G.P., Jaiswal W., Singh J. \& Malhi P. 2008. Progress in understanding ovarian follicular dynamics in cattle. Theriogenology 69:72-80.

Bertoldo M.J., Holyoake P.K., Evans G. \& Grupen C.G. 2012. Seasonal variation in the ovarian function of sows. Reprod. Fertil. Dev. 24:822834.

Cervantes M.P., Singh J., Palomino J.M. \& Adams G.P. 2013. Surgical translocation and ultrasound bio-microscopy of the ovaries in rabbits. Anim. Reprod. Sci. 138:133-141.

Comizolli P., Mermillod P. \& Mauget R. 2000. Reproductive biotechnologies for endangered mammalian species. Reprod. Nutr. Dev. 40:493-504.

Dobson H., Ghuman S., Prabhakar S. \& Smith R. 2003 A conceptual model of the influence of stress on the female reproduction. Reproduction 125:151-163.

Guimarães D.A., Garcia S.C.G., Le Pendu Y. \& Albuquerque N.I. 2011. Determinação do ciclo estral em catetos (Pecari tajacu): aspectos colpocitológicos e clínicos. Acta Amazonica 41:583-588.

Guimarães D.A., Garcia S.C.G., Ferreira M.A.P., Silva S.S.B., Albuquerque N.I. \& Le Pendu Y. 2012. Ovarian folliculogenesis in collared peccary, Pecary tajacu (Artiodactyla: Tayassuidae). Revta Biol. Trop. 60:437-455.

Hermes R., Olson D., Goritz F., Brown J., Schmitt D.L., Hagan D., Petterson J.S., Fritsch G. \& Hildebrandt T.B. 2000. Ultrasonography of the estrous cycle in female African elephants (Loxodonta africana). Zoo Biology 19:369-382.

Hildebrandt T.B., Hermes R., Jewgenow K. \& Goritz F. 2000. Ultrasonography as an important tool for the development and application of reproductive technologies in non-domestic species. Theriogenology 53:7384

Knox R.V. \& Althouse G.C. 1999. Visualizing the reproductive tract of the female pig using real-time ultrasonography. J. Swine Health Prod. 7:207215.

Lopes T.P., Sanchez-Osorio J., Bolarin A., Martinez E.A. \& Roca J. 2014. Relevance of ovarian follicular development to the seasonal impairment of fertility in weaned sows. The Vet. J. 199:382-386.
Lopes Júnior E.S., Rondina D., Simplicio A.A. \& Freitas V.J.F. 2001. Oestrus behaviour and performance in vivo of Saanen goats raised in northeast of Brazil. Livest. Res. Rural Dev. 13(6):1-10.

Macchi E., Starvaggi-Cucuzza A., Badino P., Odore R.F., Bevilacqua L. \& Malfatti A. 2010. Seasonality of reproduction in wild boar (Sus scrofa) assessed by fecal and plasmatic steroids. Theriogenology 73:1230-1237.

Mayor P., Jori F. \& López-Béjar M. 2004. Anatomic histological characteristics of the tubular genital organs of the female collared peccaries (Tayassu tajacu) from North-eastern Amazon. Anat. Histol. Embriol. 33:65-74.

Mayor P., Lopez-Gatius F. \& Lopez-Bejar M. 2005. Integrating ultrasonography within the reproductive management of the collared peccary (Tayassu tajacu). Theriogenology 63:1832-1843.

Mayor P., Guimarães D.A., Lopez-Gatius F. \& Lopez-Bejar M. 2006a. First postpartum estrus and pregnancy in the female collared peccary ( $\mathrm{Ta}$ yassu tajacu) from the amazon. Theriogenology 66:2001-2007.

Mayor P., Fenech M., Bodmer R. \& Lopez-Bejar M. 2006b. Ovarian features of the wild collared peccary (Tayassu tajacu) from the northeast Peruvian Amazon. Gen. Comp. Endocrinol. 147:268-275.

Mayor P., Galvez H., Guimarães D.A., López-Gatius F. \& López-Béjar M. 2007a. Serum estradiol-17beta, vaginal cytology and vulval appearance as predictors of estrus cyclicity in the female collared peccary (Tayassu tajacu) from the eastern Amazon region. Anim. Reprod. Sci. 97:165-174.

Mayor P., Guimarães D.A., Pendu Y.L., Silva J.V., Jori F. \& López-Béjar M. 2007b. Reproductive performance of captive collared peccaries (Tayassu tajacu) in the eastern Amazon. Anim. Reprod. Sci. 102:88-97.

McCorkell R.B., Woodbury M.R. \& Adams G.P. 2013. Serial ovarian ultrasonography in wild-caught wood bison (Bison bison athabascae). Theriogenology 80:552-556.

Ostersen T., Cornou C. \& Kristensen A.R. 2010. Detecting oestrus by monitoring sows' visits to a boar. Comp. Elect Agric. 74:51-58.

Peixoto G.C.X., Silva M.A., Castelo T.S., Silva A.M., Bezerra J.A.B., Souza A.L.P., Oliveira M.F. \& Silva A.R. Individual variation related to testicular biometry and semen characteristics in collared peccaries (Tayassu tajacu Linnaeus, 1758). Anim. Reprod. Sci. 134:191-196.

Scwarz T. \& Wierzchos E. 2010. The distribution of corpora lutea and ovarian follicular development in pregnant goats. Reprod. Biol. 10:53-66.

Souza A.L.P., Castelo T.S., Queiroz J.P.A.F., Barros I.O., Paula V.V., Oliveira M.F. \& Silva A.R. 2009. Evaluation of anesthetic protocol for the collection of semen from captive collared peccaries (Tayassu tajacu) by electroejaculation. Anim. Reprod. Sci. 116:370-375.

Waberski D., Kunz-Schmidt A., Borchadt-Neto G., Richter L. \& Weitze K.F. 1999. Real-time ultrasound diagnosis of ovulation and ovarian cysts in sows and its impact on artificial insemination efficiency. J. Anim. Sci. 77:1-8.

Wilson K.M. 1926. Histological changes in the vaginal mucosa of the sow in relation to the oestrus cycle. Am. J. Anat. 37:417-431. 